To cite this article: Clement C. Ukangwa, Evans C. Otuza \& Maria Ehioghae (2020) Influence of Information Sharing on Job Satisfaction of Librarians in Private Universities in South-East and South-West, Nigeria. Information Impact: Journal of Information and Knowledge Management, 11:4, 138-145, DOI: https://dx.doi.org/10.4314/iijikm.v11i4.13

To link to this article: https://dx.doi.org/10.4314/iijikm.v11i4.13

\title{
Digitization of Information Resources in Public Libraries and Museums in South-East, Nigeria: Problems and Prospects
}

\author{
${ }^{1}$ Kate Nkechinyere Ogbu \\ ${ }^{2}$ Abidina Abubakar \\ ${ }^{1}$ Saddiq Abdulkadir Batagarawa \\ ${ }^{1}$ Department of Library and Information Science, University of Nigeria, Nsukka \\ ${ }^{2}$ Federal College of Education Library, Katsina \\ 2Umaru Musa Yar'adua University Library, Katsina
}

\section{Abstract}

This study examines the problems and prospects of digitization of information resources in public libraries and museums in South-East, Nigeria. Two research questions were formulated to guide the study and a survey research design was also used for the study. The population of the study consists of all the staff and users of public libraries and museums in South-East, Nigeria. A total sample size of 317 was selected using a simple random sampling technique. The researcher constructed two sets of questionnaire entitled "Problems and Prospects of Digitization of Information Resources in Public Libraries and Museums Questionnaire (PPDIRPLMQ) for data collection. The instrument for data collection was trial-tested for reliability. A total 317 copies of the questionnaire were distributed to the respondents and 293 were returned and found usable by the researcher. This gave a response rate of $92 \%$. The data collected were analyzed using Mean (X) Standard Deviations and percentages to answer the research questions. Based on the data collected and analysed, the major findings of the study revealed some of the barriers to the digitization of information resources in public libraries and museums and also proffered some strategies in surmounting these challenges.

Keywords Digitization, Information resources, Public libraries, Museums

CONTACT Kate N. Ogbu, Abidina Abubakar and Saddiq A. Batagarawa kateuba2013@gmail.com Department of Library and Information Science, University of Nigeria, Nsukka, College of Education Library, Katsina and Umaru Musa Yar'adua University, Library, Katsina

2020 The Authors Published with License by Information Impact

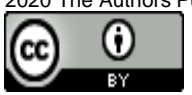




\section{Introduction}

The communities of information practitioners such as public libraries and museums have long recognized the need for new approaches to the management of information resources in their institutions. According to Saur (2001), public library is an organization established, supported and funded by the community, either through local, regional or national government or through some other form of community organization which provides access to knowledge, information and works of the imagination through a range of resources and services and is equally available to all members of the community regardless of race, nationality, age, gender, religion, language, disability, economic and employment status and educational attainment. Setshwane and Oats (2015) added that the public libraries should provide a focus for cultural and artistic development in the community they serve. On the other hand, museum according to the International Council of Museums (2010), is a non-profit making, permanent institution in the service of society and of its development, and open to the public which acquires, conserves, researches, communicates and exhibits material evidence of the people and environment for the purpose of study, education and enjoyment.

In the present changing information environment, some factors such as cost and the issues involved in digitization of objects and artifacts may jeopardize the services provided in public libraries as well as museums. To enhance easy access and management of cultural heritage in public libraries and museums, a clear policy must be formulated defining objectives, priorities and services in relation to the local community needs. To achieve this, the public library has to be organized effectively and professional standards of operation must be maintained (IFLA 1994).

There is strong motivation to bring together content from different cultural institutions into centralized portals, which have typically offered access services based on traditional catalogues used in libraries, museums and archives (Clough et al, 2015). However, the size and lack of organization of these information resources may pose a very big challenge to the users, who are provided with little or no guidance about how to access, interpret and use the information in them. Mmanaging digital cultural heritage involves a number of challenges ranging from the digitization of cultural heritage objects and artefacts to various knowledge organization challenges that include metadata, indexing and retrieval, and various user and social challenges such as information seeking and retrieval in the context of cultural heritage, digital divide and social inclusion, social and legal policy issues, and moreover long term access and sustainability issues.

According to the Directors of each of the State Library Board in South-East, Nigeria there are a total of 39 public libraries and 12 government owned museums (from the museum curators) in the area. As a matter of fact, the study was conducted in all the government owned museums and at least one public library in each state in South East Nigeria. On the other hand, the museums studied include National War Museums, Umuahia, Igboukwu National Museums in Anambra, National Museums, Abakaliki, Museums of Unity, Enugu and National Museums, Owerri.

Public libraries and museums ought to be endowed with numerous cultural resources. However, these resources have received little or no attention from both the government and local communities. Over time, the vulnerability and fragility of cultural resources have increased due to neglect, vandalism, mass tourism and poor managerial attitude etc. Also, efficient services in cultural heritage institutions may be affected by a number of factors such as the digital divide coupled with the fact that most of the practitioners of cultural resources in South East Nigeria do not have the basic internet skills to manage and disseminate digital cultural heritage information. This means that the access and management of cultural heritage information in this area may be highly jeopardized.

Due to the rapid growth in the value and variety of cultural heritage information, and the rapid growth of user-generated cultural information, cultural heritage information systems will be a growing organism requiring more and more resources to run them in years to come (Ruthven and 
Chowdhury, 2015). Therefore, digital literacy and cultural heritage information management skills and approaches have to be improved quite significantly to achieve organizational goals.

\section{Research objective}

This paper is aimed at investigating the problems and prospects of digitization of information resources: in public libraries and museums in South-East, Nigeria. However, the study specifically:

- Identified the challenges associated with digitization of information resources in public libraries and museums.

- Determined the strategies for enhancing the digitization of information resources in public libraries and museums.

\section{Research questions}

The following research questions guided the study:

- What are the challenges associated with the digitization of information resources in libraries and museums?

- What are the strategies for enhancing the digitization of information resources in libraries and museums?

\section{Literature review}

Libraries in the first decade of the twenty-first century face enormous challenges, including challenges of identity and purpose (Kenney, 2014). According to her, libraries as traditional institutions of long standing manage legacy holdings of inestimable value and as purveyors of information they are profoundly affected by the dizzying pace of technological change. Libraries constituents are more varied and more demanding than ever. Despite increasing evidence about the fragility and ubiquity of digital content, cultural repositories have been slow to respond to the need to safeguard digital heritage materials.

Ruthven and Chowdhury(2015) also noted that activities related to the development of digital libraries of cultural heritage are very resource intensive not only to begin with, for example because of the massive cost of digitization and processing of digital information, but also in the longer term of preservation of digitized heritage content that is required to ensure future access. Therefore, cultural heritage funding support, and so the economic sustainability of such services is a major issue. The organic growth of cultural heritage information systems and services also cause concerns in terms of environmental sustainability because of the increasing use of ICT infrastructure and the corresponding energy consumptions of the ICT equipment and infrastructure in order to make the digital cultural heritage information systems and services more environment-friendly. While open access to cultural heritage information will increase equity of access, this may be affected by a number of factors, such as the digital divide and information literacy. Therefore, digital literacy and information skills have to be improved quite significantly in order to enable the public to make optimum use of digital cultural heritage information systems and services.

Emphasizing the importance of user modeling and personalization - both at the specific user and community level - for cultural heritage information systems, Andissono, Kuflik and Petrelli (2012) review the evolution of personalization techniques in museum websites, virtual collections and mobile guides towards recent extensions of cultural heritage towards the semantic and social web. Oral history has remained an important part of the cultural heritage, and many audio and video collections of such cultural heritage information are now available. Specific language processing and information retrieval challenge are associated with building oral history collections. Psutka et al (2011), for example, employed novel speech recognition and information retrieval techniques to 
improve access to the Czech language part of a large video archive containing recorded testimonies of Holocaust survivors.

There are also the long-term access and sustainability issues of cultural heritage information (Ruthven \& Chowdhury, 2015). A significant amount of research resources and efforts have been made over the past decade on digital preservation, many of which focus specifically on cultural heritage information. Since most of the cultural heritage information services have appeared as an outcome of specific research projects, or have been founded by governments or individual institution such as national libraries, continuing funding support and thus the economic sustainability of such digital cultural heritage information services will remain a major concern. According to Craterre (2006), Africa is the cradle of humanity. Its natural and cultural diversity are matched only by its long history. Little attention, however, is paid to cultural and heritage policies in African local governments' action strategies. This lack of interest expresses itself in various ways. Most African cities do not have museums worthy of the name. Few have established a proper inventory of their natural and cultural heritage. Many do not have mechanisms for the classification or safeguarding of their heritage. Very few are aware of the World Heritage Convention and this puts Africa at risk of being marginalized. However, Yankova (2012) is of the view that the modern library is a navigator, manufacturer and mediator between the producers of information and its users (Certo and Trevis (2005). It is an important factor in contemporary global communication.

\section{Methodology}

The researcher used a survey research design to study the problems and prospects of digitization of information resources in public libraries and museums. The institutions covered in this study are public libraries and government owned museums. The population of study comprised the staff and users of these public libraries and museums. The population size is about 31,759 while the sample size is $317(1 \%)$ of the entire population. This agrees with Mendenhall and Reinmuth (2004) where it was stated that when a population is uniform, a small sample provides the sample amount of information as a large sample. Two sets of a structured questionnaire were constructed by the researcher as instrument for data collection. The instrument was validated by two experts in the Department of Library and Information Science and one other expert in the Department of Science Education, Measurement and Evaluation Unit, all from the University of Nigeria, Nsukka. Their recommendations and modifications were incorporated appropriately into the instrument for data collection. The reliability of the instruments was determined through a pilot test. Copies of the instruments were administered randomly to twenty (20) staff and users of the Benue State Public Library. Cronbach's Alpha Reliability method was used to determine the internal consistency of the items in the two sets of the questionnaire and they showed the reliability index of 0.95 and 0.65 respectively. A total of 317 copies of the questionnaire were distributed among the staff and users of these public libraries and museums within the area of interest. The questionnaires were administered through hand to hand delivery to the respondent. Out of this number, only 293 (92\%) copies were returned and found usable by the researcher. The analysis was therefore made base on 293 copies of the questionnaires returned. The data collected for this study was analysed and tabulated using mean, standard deviations and percentages. Any mean score equal to or above 2.50 was regarded as positive and acceptable while any mean less than 2.50 was regarded as negative and unacceptable. In addition, any percentage that ranges from $50 \%$ and above was seen as positive and acceptable while percentage that is below $50 \%$ was taken to be negative and unacceptable. 


\section{Result}

Research Question 1: What are the challenges associated with the digitization of information resources in public libraries and museums?

Table 1: Mean Ratings of Challenges Associated with the Digitization of Information Resources in Public Libraries and Museums

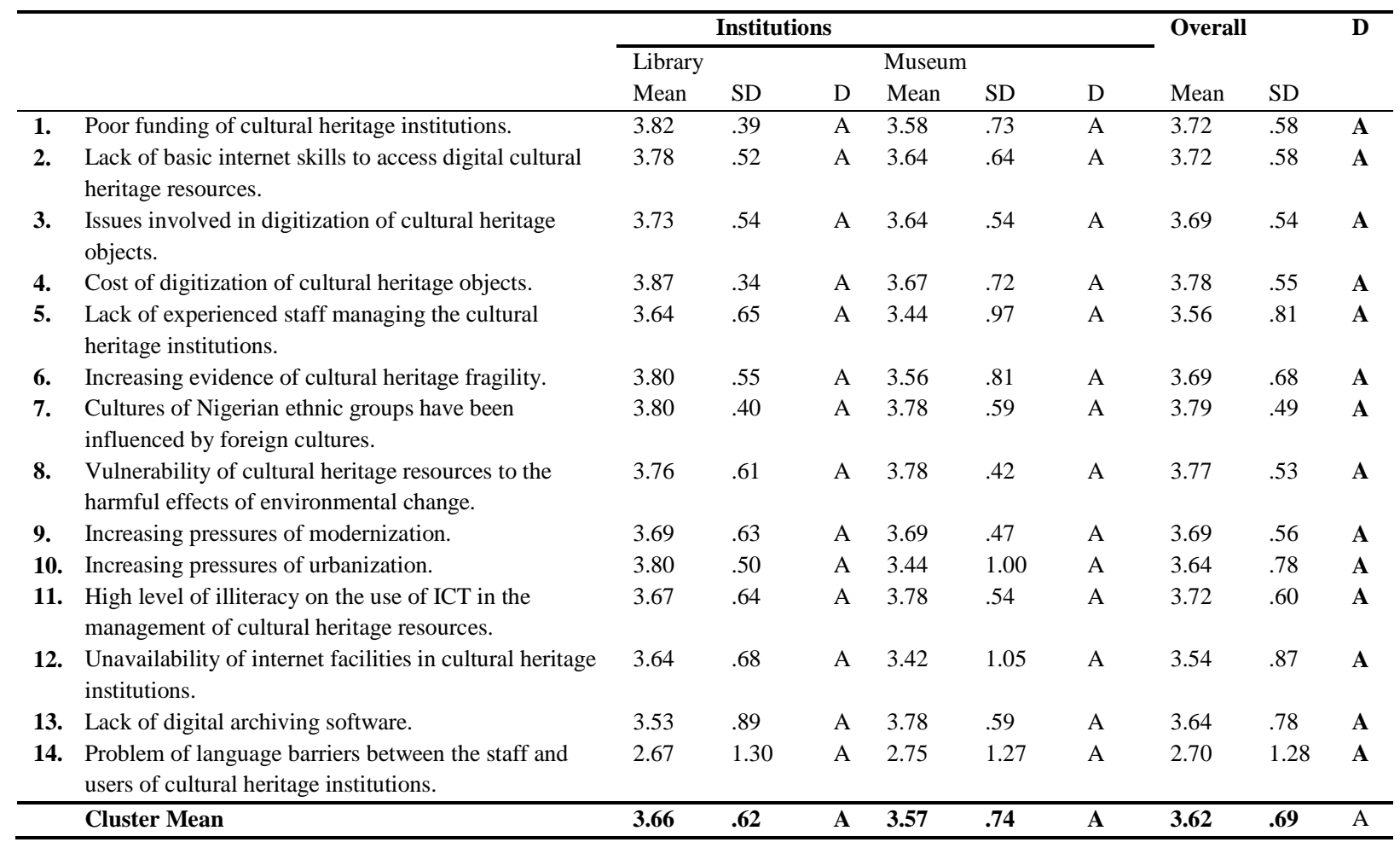

The data presented in Table 1 revealed that all the items were above the cut-off point of 2.50 on a 4 point rating scale. Looking at the two institutions used in the study, the public library institutions had greater mean of $\left.{ }^{\bar{X}}=3.66, \mathrm{SD} .62\right)$ as against museums (mean=3.57, SD.74). However, the above findings showed that the respondents agreed that all the above items are challenges associated with the digitization of information resources in libraries and museums.

Research Question 2: What are the strategies for enhancing the digitization of information resources in public libraries and museums?

Table 2: Mean Ratings of Strategies for Enhancing the Digitization of Information Resources in Public Libraries and Museums

\begin{tabular}{|c|c|c|c|c|c|c|c|c|c|c|}
\hline & & \multicolumn{5}{|c|}{ Institutions } & & \multirow{2}{*}{\multicolumn{2}{|c|}{ Overall }} & \multirow[t]{3}{*}{$\mathrm{D}$} \\
\hline & & \multicolumn{3}{|l|}{ Library } & \multicolumn{3}{|c|}{ Museum } & & & \\
\hline & & Mean & $\mathrm{SD}(\mathrm{D})$ & & Mean & $S D(D)$ & & Mean & SD & \\
\hline 1. & $\begin{array}{l}\text { Preserving cultural heritage memory in } \\
\text { analogue forms. }\end{array}$ & 3.51 & .97 & VA & 3.00 & 1.26 & $A$ & 3.28 & 1.13 & $\mathbf{A}$ \\
\hline 2. & $\begin{array}{l}\text { Preserving cultural heritage memory in digital } \\
\text { forms. }\end{array}$ & 3.22 & 1.11 & A & 3.39 & .96 & $A$ & 3.30 & 1.04 & A \\
\hline 3. & $\begin{array}{l}\text { Audio-visual materials should be used to } \\
\text { disseminate information on Nigerian culture. }\end{array}$ & 3.24 & 1.09 & A & 3.28 & 1.09 & $A$ & 3.26 & 1.08 & A \\
\hline 4. & $\begin{array}{l}\text { ICT materials should be used to disseminate } \\
\text { information on Nigerian culture. }\end{array}$ & 3.64 & .80 & VA & 3.44 & .91 & $A$ & 3.56 & .85 & VA \\
\hline 5. & $\begin{array}{l}\text { Internet should be used to access cultural } \\
\text { heritage resources in cultural heritage }\end{array}$ & 3.71 & .63 & VA & 3.44 & .91 & $A$ & 3.59 & .77 & VA \\
\hline
\end{tabular}




\begin{tabular}{|c|c|c|c|c|c|c|c|c|c|c|}
\hline & institutions. & & & & & & & & & \\
\hline 6. & $\begin{array}{l}\text { Recruitment of experienced staff able to use a } \\
\text { range of management techniques which should } \\
\text { sustain the existence of cultural heritage in } \\
\text { cultural heritage institutions. }\end{array}$ & 3.49 & .92 & A & 3.69 & .62 & VA & 3.58 & .80 & VA \\
\hline 7. & $\begin{array}{l}\text { Public partnership for digitization of cultural } \\
\text { heritage resources should be encouraged. }\end{array}$ & 3.69 & .73 & VA & 3.67 & .72 & VA & 3.68 & .72 & VA \\
\hline 8. & $\begin{array}{l}\text { Government should foster public-private } \\
\text { partnership in order to share the gigantic cost } \\
\text { of cultural heritage digitization }\end{array}$ & 3.60 & .78 & VA & 3.72 & .51 & VA & 3.65 & .67 & VA \\
\hline 9. & $\begin{array}{l}\text { Cultural heritage institutions should develop } \\
\text { interactions with other digital cultural heritage } \\
\text { collections in the world using a range of tools } \\
\text { and also using the feedback to improve their } \\
\text { experience. }\end{array}$ & 3.73 & .65 & VA & 3.50 & .91 & VA & 3.63 & .78 & VA \\
\hline 10. & $\begin{array}{l}\text { Cultural heritage institutions should monitor } \\
\text { interactions with other digital cultural heritage } \\
\text { collections in the world using a range of tools } \\
\text { and also using the feedback to improve their } \\
\text { experience. }\end{array}$ & 3.80 & .59 & VA & 3.75 & .55 & VA & 3.78 & .71 & VA \\
\hline 11. & $\begin{array}{l}\text { Cultural heritage institutions should adapt to } \\
\text { the rapid development in ICT. }\end{array}$ & 3.42 & .99 & A & 3.72 & .70 & VA & 3.56 & .88 & VA \\
\hline 12. & $\begin{array}{l}\text { Change should be introduced with maximum } \\
\text { effectiveness and the least stress on staff and } \\
\text { organization. }\end{array}$ & 3.76 & .57 & VA & 3.83 & .38 & VA & 3.79 & .79 & VA \\
\hline 13. & $\begin{array}{l}\text { There should be adequate resources in various } \\
\text { formats to support new services in cultural } \\
\text { heritage institutions. }\end{array}$ & 3.89 & .72 & VA & 3.64 & .72 & VA & 3.78 & .87 & VA \\
\hline 14. & $\begin{array}{l}\text { There should be qualified staff to support new } \\
\text { services in cultural heritage institutions. }\end{array}$ & 3.49 & .87 & A & 3.75 & .73 & VA & 3.60 & .82 & VA \\
\hline 15. & $\begin{array}{l}\text { Precautionary principle during the management } \\
\text { of cultural heritage should be applied to avoid } \\
\text { irreversible damage or loss. }\end{array}$ & 3.91 & .29 & VA & 3.75 & .69 & VA & 3.84 & .91 & VA \\
\hline 16. & $\begin{array}{l}\text { There should be a good maintenance of } \\
\text { awareness of the interconnectedness of the } \\
\text { cultural, economic, social, and environmental } \\
\text { systems. }\end{array}$ & 3.67 & .71 & A & 3.53 & .81 & VA & 3.60 & .75 & VA \\
\hline & Cluster Mean & 3.61 & .75 & VA & 3.56 & .78 & VA & 3.59 & .78 & VA \\
\hline
\end{tabular}

Examining the two institutions used in the study, the public library institutions had greater mean and standard deviation of $\left({ }^{X}=3.61 \mathrm{SD}=.75\right)$ as against museum institutions $(\mathrm{M}=3.56 \mathrm{SD}=.78)$. This suggests that the respondents from public libraries favored these items than those in museums. Finally the overall mean score of 3.59 with a corresponding standard deviation value of .78 shows that the respondents believed that items in the cluster are very appropriate strategies.

\section{Discussion}

A number of factors were identified by staff as challenges hindering the digitization of information resources in public libraries and museums. The staff identified barriers to do with "cultures of Nigerian ethnic groups have been influenced by foreign cultures and cost of digitization of cultural heritage objects" as the greatest challenges associated with the digitization of information resources in public libraries and museums. The findings of Ruthven and Chowdhury(2015) also found out that activities related to the development of digital libraries of cultural heritage are very resource intensive. Poor funding of cultural heritage institutions, lack of basic internet skills to access digital cultural heritage resources and high level of illiteracy on the use of ICT in the management of cultural resources were also identified as major barriers to the digitization of information resources in public libraries and museums. These findings are justified by Mamman (2015) who also observed that some 
of the barriers to effective utilization of ICTs in public libraries were inadequate funding, staff low level of computer literacy, inadequate ICT infrastructure and low level of ICT awareness among users.

Other barriers to the digitization of information resources in these institutions have to do with lack of digital archiving software etc. Gaur (2013) also observed that technological obsolescence, economic barriers, lack of digital archiving software, language barriers and copyright issues are among the challenges facing the access and management of cultural heritage in public libraries. He noted that the conversion of these materials into new form of multimedia technologies is very expensive and Kazi (2012) added that both museums and libraries face an ongoing battle to justify their existence and secure their futures. The result of the findings showed that the staff of public libraries and museums accepted the measures for enhancing the digitization of information resources in these institutions. The respondents agreed that ICT materials should be used to disseminate information on Nigerian culture and that cultural heritage institutions should adapt to the rapid development in ICT in addition to preserving cultural heritage memory in digital forms. The findings of this research is in line with that of Sula (2015) who stressed that cultural heritage institutions should do everything they can to digitize materials as quickly as possible. These efforts make collections available to a much broader range of users. Similarly, Mamman (2015) recommended in his study that state government should adequately fund public libraries and that public library authorities should sponsor their staff to ICT - related workshops and training, partner with other agencies in ensuring the provision of ICT facilities and should organize workshops and seminars on ICT literacy for library users.

\section{Conclusion and Recommendations}

Digitization is a current and contemporary improvement providing libraries as information centres in terms of protecting and accessing information with new opportunities. ICT has come to change every element of information services from technical operations to digital in libraries and museums and these institutions are among the leading fields that ICT affect in the most intensive and quick way. It is inevitable for public libraries and museums to use this contemporary opportunity and to reflect it in their operations and services. To this end, the following is recommended:

1) Government at all levels should provide adequate financial resources for the proper management of information resources in both public libraries and museums.

2) Public libraries and museums should adapt to the rapid development in ICT in addition to preserving cultural heritage memory in digital forms.

3) Public libraries and museums should partner with other institutions in ensuring the provision of ICT facilities and also to share the high cost of digitization.

\section{References}

Ardissono, L., Kuflik, T. \& Petrelli, D. (2012). Personalization in cultural heritage: the road travelled and the one ahead, modeling and user-adapted interaction, 22(1-2), 73-99.

Certo, S. \& Trevis C. (2005). Modern library management. The changing role of the ILS. A white paper, talis alto. (Version 1.0).

Chowdhury, G., 2014. Sustainability of digital libraries: a conceptual model and a research framework. International Journal on Digital Libraries, 14 (3-4), 181-195. doi:10.1007/s00799-014-0116-0. 
Clough P., Goodale P., Hall M. \& Stevenson M. (2015). Supporting exploration and use of digital cultural heritage materials: the PATHS perspective, University of Sheffield, UK.

CRAterre-ENSAG (2006) A guide for African local governments cultural heritage and local development convention, France-UNESCO

Gaur, R. C.(2013). Facilitating access to Indian cultural heritage: copyright, permission rights and ownership issues vis-à-vis IGNCA collections.

IFLA/UNESCO public library manifesto, 1994.

International Council of Museums [ICOM] (2010). ICOM Missions. http://icom.museum/

Kazi, N., (2012). The identity crisis of libraries in the attention economy. Library Philosophy and Practice (e-journal), 1 January. Available from: http://digitalcommons.unl.edu/libphilprac/684?utm_source=digitalcommons.unl.edu\%2Flibph ilprac\%2F684\&utm_medium=PDF\&utm_campaign=PDFCoverPages [Google Scholar]

Kenney, R. (2014). Collections, preservation and the changing resource base.

Mamman, E. (2015). Utilization of information and communication technologies (ICTs) in public services in Nigeria.

Mendenhall,W.\& Reinmuth,J.E. (2004). Statistics for management and economics. $5^{\text {th }}$ edition. North Seituate,Mass:Duxbury Press.

Psutka, J., Svec, J., Psutka, J. V., Vanek, J., Prazak, A., Smidl, L. \& Ircing, P. (2011) System for fast lexical and phonetic spoken term detection in a czech cultural heritage archive, Eurasip Journal on Audio Speech and Music Processing, Article Number 10, 1-1, DOI: 10.1186/16874722-2011-10. 62(2), 314-42

Ruthven, I. \& Chowdhury G. (2015). Cultural heritage information access and management.

Ruthven, I. \& Chowdhury, G. (2014). Sustainability of digital libraries: a conceptual model and a research framework. International Journal on Digital Libraries, 14 (3-4), 181-195. doi:10.1007/s00799-014-0116-0.

Saur, München K.G. (2001). The public library service: IFLA/UNESCO guidelines for development, prepared by a working group chaired by Philip Gill on behalf of the section of public libraries.

Setshwane,S.M. \& Oats L. (2015) Cultural preservation through public libraries: lessons from Kanye Public Library. available under the terms of the Creative Commons Attribution 3.0 Unported License: http://creativecommons.org/licenses/by/3.0/

Sula, C. (2015). Digital humanities and digital cultural heritage (alt-history and future directions).

Yankova, I. (2012). Library management-contemporary challenges in library information and cultural heritage management. textbook.

Yilmaz, B. (2012). Digitizing cultural heritage, Europeana and public libraries 